\title{
Quality of financial information and liquidity
}

\author{
Keyhan Maham ${ }^{\mathrm{a}}$ and Fahime Safikhani ${ }^{\text {* }}$
}

${ }^{a}$ Assist. Prof. \& Faculty Member, Department of Accounting, School of Management and Accounting, Ghazvin Branch, Islamic Azad University (IAU), Ghazvin, Iran

${ }^{b}$ M.A. Student, Department of Accounting, School of Management and Accounting, Ghazvin Branch, Islamic Azad University (IAU), Ghazvin, Iran

\section{H R O N I C L E}

Article history:

Received February 252014

Accepted 17 July 2014

Available online

July 202014

Keywords:

Quality of financial information

Financial statement restatements

Liquidity

Information asymmetry

\section{A B S T R A C T}

\begin{abstract}
This paper examines the relationship between liquidity and quality of financial information by analyzing long-term trends in illiquidity measure for firms that restate their financial statements. The study uses a method developed by Amihud (2002) [Amihud, Y. (2002). Illiquidity and stock returns: cross-section and time-series effects. Journal of financial markets, 5(1), 31-56.]. The original sample consists of 98 listed firms in Tehran Stock Exchange over the period 2004-2011. In this study, the measurement of quality of financial information is associated with presence or absence of financial restatement cases. We find that for most income decreasing restatements illiquidity increases before restatement announcement and this increase continues after restatement announcement. Overall, our results indicate a positive relationship between quality of financial information and liquidity.
\end{abstract}

\section{Introduction}

Nowadays, earnings adjustment plays essential role on investment strategies (Kryzanowski \& Zhang, 2013; Liu, 2006; Marcelo et al., 2006). Regulators are also concerned that during the process of restating financial statements, companies may fail to provide timely progress updates, and delay earnings announcements and regulatory filings. To reduce these perceived lags in such disclosure, an advisory team to the Securities and Exchange Commission suggests more use of catch-up adjustments rather than restatements to correct accounting errors. Some investor groups may also oppose the recommendations because they may feel that preparers could begin to correct important errors through catch-up adjustments, which would become less transparent than restatements. Badertscher and Burks (2011) examined the length of disclosure lags around restatements to understand the extent of the problem, and the causes of disclosure lags to evaluate whether the reforms would address the root causes of the lags. They reported that lengthy lags were uncommon. When fraud was a factor, the firm takes weeks or months to disclose restatement details, quarterly earnings, and SEC filings, 
probably because studies were necessary to restore the firm's ability to produce good information. When fraud is not a case, the firm may disclose the restatement's earnings impact within a day of the initial restatement announcement, and delays the quarterly earnings announcement and SEC filing by less than a week.

Bardos (2011) examined the relationship between liquidity and quality of financial information by investigating long-term trends in Amihud's (2002) illiquidity figure for firms that restate financial statements. The author reported that for most income decreasing restatements illiquidity could increase several months before restatement announcement and it could stay at elevated levels one year after restatement. Increase in illiquidity was bigger upon restatements due to revenue recognition, those prompted by party other than auditor, those made by larger companies with high volatility of returns and low price levels. Income increasing restatements, in this study, did not influence information asymmetry of the company. The results stated a positive relationship between quality of financial information and liquidity.

Chung et al. (2009) studied the relationship between earnings management and equity liquidity, positing that as incentives arise for the manipulation of firm performance through earnings management, bigger earnings management could signal higher adverse selection expenses. If earnings manipulation disclosed aggressive accounting practices, liquidity providers would become widen bidask spreads to protect themselves. They reported that firms with higher earnings management could suffer lower equity liquidity.

$\mathrm{Ng}$ (2011) investigated whether or not information quality could influence the cost of equity capital through liquidity risk. Liquidity risk was the sensitivity of stock returns to unexpected changes in market liquidity; recent asset pricing literature had emphasized the importance of this systematic risk. $\mathrm{Ng}$ reported that higher information quality was associated with lower liquidity risk and that the reduction in cost of capital due to this association was economically substantial. The author also reported that the negative association between information quality and liquidity risk was stronger in times of large shocks to market liquidity.

Kiel and Nicholson (2003) examined the relationships between board demographics and corporate performance in some Australia's largest publicly listed firms and described the attributes of these firms and their boards. They reported that, after controlling for firm size, board size was positively associated with firm value. They also reported a positive relationship between the proportion of inside directors and the market-based measure of firm performance. Leuz and Wysocki (2006) investigated the relationship between the effects of capital-market corporate disclosures and disclosure regulation.

\section{The proposed study}

This paper examines the relationship between liquidity and quality of financial information by analyzing long-term trends in illiquidity measure for firms that restate their financial statements. The study uses a method developed by Amihud (2002). There are three hypotheses associated with the proposed study of this paper as follows,

1. The change in liquidity is different from the time a firm reports a negative adjustment in net profit to the time a firm reports a positive adjustment in net profit.

2. Any adjustment on net profit will reduce liquidity of the firm before announcement.

3. Any adjustment on net profit will reduce liquidity of the firm after announcement. 
The original sample consists of 98 listed firms in Tehran Stock Exchange (TSE) over the period 2004-2011. To collect the data, we exclude financial, holding, insurance firms. In addition, only firms whose ticker symbol was accepted on exchange prior to 2004 were accepted. Moreover, all firms must have the same fiscal calendar and all necessary information must be available over the period of investigation. Finally, there must be no significant interruption on trading activities and there must be a $10 \%$ change in profit estimate in their earnings forecast compared with prior year. There are three set of independent variables, dependent variable and control variables. In our study, illiquidity is the dependent variable, which is calculated as follows,

$I L L I Q_{i d}=\frac{\left|R_{i d}\right|}{V O L D_{i d}} \times 10^{6}$,

where $I L L I Q_{i d}$ represents illiquidity of firm $i$ for day $d, R_{i d}$ represents return of firm $i$ for day $d$ and $V O L D_{i d}$ represents trading volume of firm $i$ for day $d$. This variable for each hypothesis is calculated separately at three different times. In our study, $\triangle \mathrm{ILLIQ} 1$ is associated with changes in liquidity of firms with negative forecast in net profit and $\triangle$ ILLIQ2 is associated with changes in liquidity of firms with positive forecast in net profit. In addition, $\triangle$ ILLIQ is associated with positive/negative forecast in net profit. The proposed study of this paper uses the following regression analysis to study the relationship between illiquidity and other independent variables

$$
\Delta I L L I Q_{3}=\alpha+\beta_{1} \text { Revenue }_{\mathrm{i}}+\beta_{2} \text { IRS }+\beta_{3} \text { Auditor }_{\mathrm{i}}+\beta_{4} \text { Decreasing income }+\Omega_{\text {Controls }_{\mathrm{i}}}+\varepsilon_{i}
$$

where $\triangle I L L I Q_{3}$ represents illiquidity measures defined by Amihud (2002), Revenue is a dummy variable, which is one when the new statement represents a reduction on revenue and zero, otherwise. $I R S$ is another dummy variable, which is one if the change in statement is the result of tax and zero, otherwise. Auditor is the other variable, which is one if the change in statement is associated with auditor and zero, otherwise. Moreover, Decreasing income is the other dummy variable, which is one if the restatement represents a negative effect and zero, otherwise. Controls and $\varepsilon_{i}$ are control variable and residuals, respectively. Finally, $\alpha, \beta_{1}, \beta_{2}, \beta_{3}, \beta_{4}$ and $\Omega$ coefficients, which are estimated by regression technique. There are three control variables in our survey. The first control variable is associated with natural logarithm of the mean of adjusted price, Ln $P_{i d}$, the second variable, $\mathrm{Ln}$ $\left(M V \times P_{i d}\right)$ is calculated by taking logarithm of market value (MV) by $P_{i d}$. Finally, the last control variable is measured by taking natural logarithm on daily return $R_{i d}$. Table 1 demonstrates some of basic statistics associated with the proposed study of this paper.

Table 1

The summary of some basic statistics

\begin{tabular}{lccccccc}
\hline Variable & Mean & Median & Std. Dev. & Skewness & Kurtosis & Min & Max \\
\hline$\Delta$ ILLIQ $_{1}$ & -0.036 & 0.0001 & 1.518 & 0.246 & 9.688 & -6.239 & 6.656 \\
ILLIQ $_{2}$ & -0.086 & 0.004 & 2.261 & -2.796 & 26.631 & -16.978 & 9.674 \\
$\Delta$ ILLIQ $_{3}$ & -0.095 & -0.0003 & 2.209 & -0.473 & 22.755 & -14 & 13.067 \\
Decreasing income & 0.829 & 1 & 0.377 & -1.773 & 1.162 & 0 & 1 \\
Increasing income & 0.170 & 0 & 0.377 & -1.773 & 1.162 & 0 & 1 \\
Revenue & 0.141 & 0 & 0.349 & 2.089 & 2.401 & 0 & 1 \\
IRS & 0.585 & 1 & 0.495 & -0.350 & -1.906 & 0 & 1 \\
Auditor & 0.274 & 0 & 0.448 & 1.024 & -0.965 & 0 & 1 \\
$\operatorname{Ln}\left(\mathrm{P}_{\text {it }}\right)$ & 3.519 & 3.508 & 0.376 & 0.286 & -0.625 & 2.815 & 4.412 \\
$\operatorname{Ln}(\mathrm{MV})$ & 11.439 & 11.363 & 0.650 & 0.585 & 0.298 & 10.048 & 13.314 \\
$\operatorname{Ln}\left(\operatorname{std}\left(\mathrm{R}_{\text {it }}\right)\right)$ & 0.611 & 0.621 & 0.468 & 0.293 & 0.240 & -0.556 & 2.061 \\
\hline
\end{tabular}


The information of Kurtosis on different variables indicates that they are fairly close to normal distribution. In addition, Table 2 and Table 3 present details of Pearson correlation ratios between different pairs of variables associated with the second and the third hypotheses, respectively.

Table 2

The summary of Pearson correlation ratios for variables associated with the second hypothesis

\begin{tabular}{|c|c|c|c|c|c|}
\hline & & $\Delta$ ILLIQ $_{2}$ & $\log \left(p_{i}\right)$ & $\log \left(\operatorname{std}\left(\mathrm{R}_{\mathrm{i}}\right)\right)$ & $\log (\mathrm{MV})$ \\
\hline & $r$ & 1 & -0.036 & -0.093 & -0.054 \\
\hline$\Delta \mathrm{ILLIQ}_{2}$ & Sig. & & 0.684 & 0.291 & 0.540 \\
\hline $\log \left(p_{i}\right)$ & $\mathrm{r}$ & & 1 & $0.465^{*}$ & $0.420^{*}$ \\
\hline & Sig. & & & 0.000 & 0.000 \\
\hline $\log \left(\operatorname{std}\left(\mathrm{R}_{\mathrm{i}}\right)\right)$ & $r$ & & & 1 & $0.220^{*}$ \\
\hline & Sig. & & & & 0.010 \\
\hline $\log (\mathrm{MV})$ & $r$ & & & & 1 \\
\hline & Sig. & & & & - \\
\hline
\end{tabular}

Table 3

The summary of Pearson correlation ratios for variables associated with the third hypothesis

\begin{tabular}{|c|c|c|c|c|c|}
\hline & & $\Delta \mathrm{ILLIQ}_{3}$ & $\log \left(p_{i}\right)$ & $\log \left(\operatorname{std}\left(R_{i}\right)\right)$ & $\log (\mathrm{MV})$ \\
\hline \multirow[t]{2}{*}{$\Delta \mathrm{ILLIQ}_{3}$} & $r$ & 1 & -0.142 & -0.048 & -0.083 \\
\hline & Sig. & & 0.103 & 0.582 & 0.354 \\
\hline \multirow[t]{2}{*}{$\log \left(p_{i}\right)$} & $r$ & & 1 & $0.465^{*}$ & $0.420^{*}$ \\
\hline & Sig. & & & 0.000 & 0.000 \\
\hline \multirow[t]{2}{*}{$\log \left(\operatorname{std}\left(R_{\mathrm{i}}\right)\right)$} & $\mathrm{r}$ & & & 1 & $0.220^{*}$ \\
\hline & Sig. & & & & 0.010 \\
\hline \multirow[t]{2}{*}{ Log (MV) } & $\mathrm{r}$ & & & & 1 \\
\hline & Sig. & & & & \\
\hline
\end{tabular}

As we can observe from the results of Table 2 and Table 3, there are not meaningful relationships between different variables of the survey.

\section{The results}

In this section, we present details of our findings on testing three hypotheses of the survey.

\subsection{The first hypothesis: The effect of positive or negative adjustment}

The first hypothesis of the survey investigates whether the change in liquidity is different from the time a firm reports a negative adjustment in net profit to the time a firm reports a positive adjustment in net profit. Table 4 demonstrates the results of our survey on testing between the mean of positive and negative earnings adjustment.

Table 4

The result of comparing mean difference between negative versus positive earnings

\begin{tabular}{|c|c|c|c|c|c|c|c|c|c|c|}
\hline \multirow[b]{2}{*}{ Variable } & \multirow[b]{2}{*}{$\mathrm{N}$} & \multirow[b]{2}{*}{ Mean } & \multirow[b]{2}{*}{ Std. diff. } & \multicolumn{3}{|c|}{$\mu_{1}=\mu_{2}$} & \multirow{2}{*}{$\begin{array}{c}\text { Mean } \\
\text { difference }\end{array}$} & \multicolumn{3}{|c|}{$\sigma_{1}^{2}=\sigma_{2}^{2}$} \\
\hline & & & & $\mathrm{t}$-value & $\mathrm{df}$ & Sig. & & F-value & $\mathrm{df}$ & Sig. \\
\hline Neg. adj. & 112 & 0.4245 & 4.38986 & & 133 & 0015 & & 1059 & 133 & \\
\hline Pos. adj. & 23 & 0.2611 & 4.21214 & 2.068 & 133 & 0.015 & 0.1634 & 1.059 & 133 & 0.305 \\
\hline
\end{tabular}

The results of Table 4 indicate that the mean difference between two adjustments is significance $(\alpha=$ $5 \%$ ). In addition, the negative adjustment has more effect than positive adjustment on liquidity. Therefore, the first hypothesis of the survey has been confirmed. 


\subsection{Testing the second hypothesis: The effect of adjustment before announcement}

The second hypothesis of the survey investigates whether or not any adjustment on net profit will reduce liquidity of the firm before announcement. Table 5 demonstrates the results of our survey on testing this hypothesis.

Table 5

The results of testing the effect of adjustment before announcement

\begin{tabular}{|c|c|c|c|c|c|c|}
\hline & \multicolumn{2}{|c|}{ Non-standard coefficients } & \multirow{2}{*}{$\frac{\text { Standard coefficients }}{\beta}$} & \multirow[b]{2}{*}{ t-value } & \multirow[b]{2}{*}{ Sig. } & \multirow[t]{2}{*}{ VIF } \\
\hline & $\beta$ & Standard error & & & & \\
\hline$\alpha$ & 2.837 & 0.266 & & 10.670 & 0.000 & \\
\hline Decreasing income & 0.093 & 0.040 & 0.205 & 2.339 & 0.021 & 1.036 \\
\hline Revenue & -0.054 & 0.044 & -0.112 & -1.229 & 0.221 & 1.128 \\
\hline IRS & 0.010 & 0.031 & 0.030 & 0.333 & 0.740 & 1.116 \\
\hline Auditor & 0.029 & 0.035 & 0.078 & 0.849 & 0.397 & 1.143 \\
\hline $\operatorname{Ln}\left(P_{i t}\right)$ & 0.012 & 0.047 & 0.027 & 0.250 & 0.803 & 1.521 \\
\hline $\operatorname{Ln}\left(\operatorname{std}\left(\mathrm{R}_{\mathrm{it}}\right)\right)$ & -0.036 & 0.035 & -0.102 & -1.039 & 0.301 & 1.290 \\
\hline $\operatorname{Ln}(\mathrm{MV})$ & -0.009 & 0.025 & -0.034 & -0.342 & 0.733 & 1.319 \\
\hline
\end{tabular}

The results of Table 5 demonstrate that the coefficient associated with the variable, Decreasing income, was positive and it is statistically significance. In addition, VIF is equal to $1.036<5$, which means there was no strong correlation between independent variables. Moreover, Durbin-Watson value is equal to 1.992, which means there was not any auto correlation among residuals. Finally, adjusted R-Square indicates that the independent variables could describe approximately $7 \%$ of the changes on dependent variable. Therefore, we can confirm the second hypothesis.

\subsection{The third hypothesis: The effect of adjustment after announcement}

The third hypothesis of the survey investigates whether or not any adjustment on net profit will reduce liquidity of the firm after announcement. Table 6 shows the results of our survey on testing this hypothesis.

Table 6

The results of testing the effect of adjustment after announcement

\begin{tabular}{|c|c|c|c|c|c|c|}
\hline & \multicolumn{2}{|c|}{ Non-standard coefficients } & \multirow{2}{*}{$\begin{array}{c}\text { Standard coefficient } \\
\text { Beta }\end{array}$} & \multirow[t]{2}{*}{ t-value } & \multirow[t]{2}{*}{ Sig. } & \multirow[t]{2}{*}{ VIF } \\
\hline & $\beta$ & Standard error & & & & \\
\hline$\alpha$ & 2.784 & 3.487 & & 0.798 & 0.426 & \\
\hline Decreasing Income & 1.439 & 0.512 & 0.239 & 2.813 & 0.006 & 1.230 \\
\hline Revenue & 0.125 & 0.579 & 0.019 & 0.215 & 0.830 & 1.450 \\
\hline IRS & -0.710 & 0.403 & -0.156 & -1.761 & 0.081 & 1.200 \\
\hline Auditor & 0.571 & 0.457 & 0.110 & 1.238 & 0.222 & 1.010 \\
\hline $\log \left(\mathrm{P}_{\mathrm{it}}\right)$ & -0.751 & 0.611 & -0.126 & -1.229 & 0.222 & 1.800 \\
\hline $\left.\log \left(\operatorname{stdR}_{\mathrm{it}}\right)\right)$ & 0.162 & 0.454 & 0.034 & 0.357 & 0.722 & 1.470 \\
\hline $\log (\mathrm{MV})$ & -0.085 & 0.332 & -0.025 & -0.257 & 0.798 & 1.630 \\
\hline
\end{tabular}

The results of Table 6 show that the coefficient associated with the variable, Decreasing income, was positive and it is statistically significance. In addition, VIF is equal to $1.23<5$, which means there was no strong correlation between independent variables. Moreover, Durbin-Watson value is equal to 2.019, which means there was not any auto correlation among residuals. Finally, adjusted R-Square indicates that the independent variables could describe approximately $8 \%$ of the changes on dependent variable. Therefore, we can confirm the third hypothesis. 


\section{Conclusion}

In this paper, we have presented an empirical investigation to study the impact of earnings adjustment on liquidity on selected firms listed on Tehran Stock Exchange. The results of our survey have confirmed that the change in liquidity was different from the time a firm reports a negative adjustment in net profit to the time a firm reports a positive adjustment in net profit. In addition, the results of our survey have indicated that any adjustment on net profit will reduce liquidity of the firm before or after announcement.

\section{Acknowledgement}

The authors would like to thank the anonymous referees for constructive comments on earlier version of this paper.

\section{References}

Amihud, Y. (2002). Illiquidity and stock returns: cross-section and time-series effects. Journal of Financial Markets, 5(1), 31-56.

Badertscher, B. A., \& Burks, J. J. (2011). Accounting restatements and the timeliness of disclosures. Accounting Horizons, 25(4), 609-629.

Bardos, K. S. (2011). Quality of financial information and liquidity. Review of Financial Economics, 20(2), 49-62.

Chung, H., Sheu, H. J., \& Wang, J. L. (2009). Do firms' earnings management practices affect their equity liquidity?. Finance Research Letters, 6(3), 152-158.

Kiel, G. C., \& Nicholson, G. J. (2003). Board composition and corporate performance: how the Australian experience informs contrasting theories of corporate governance. Corporate Governance: An International Review, 11(3), 189-205.

Kryzanowski, L., \& Zhang, Y. (2013). Financial restatements by Canadian firms cross-listed and not cross-listed in the US. Journal of Multinational Financial Management, 23(1), 74-96.

Leuz, C., \& Wysocki, P. (2006). Capital-market effects of corporate disclosures and disclosure regulation. Research Study, Commissioned by the Task Force to Modernize Securities Legislation in Canada, 183-236.

Liu, W. (2006). A liquidity-augmented capital asset pricing model. Journal of financial Economics, 82(3), 631-671.

Marcelo, J. L. M., \& Quirós, M. D. M. M. (2006). The role of an illiquidity risk factor in asset pricing: Empirical evidence from the spanish stock market. The Quarterly Review of Economics and Finance, 46(2), 254-267.

$\mathrm{Ng}$, J. (2011). The effect of information quality on liquidity risk. Journal of Accounting and Economics, 52(2), 126-143. 